DOI: 10.17707/AgricultForest.63.4.18

\author{
Borislav RAILIĆ, Zoran MALIČEVIĆ, \\ Dragoljub MITROVIĆ, Ljiljana DRINIĆ, Stevan TRIVKOVIĆ ${ }^{1}$
}

\title{
PRODUCTIVITY OF TRANSPORT AGGREGATES IN HARVESTING CORN GRAINS
}

\begin{abstract}
SUMMARY
Transport in plant production includes the entire transport of products and raw material from the place of production to the storehouse. Participation of transport in plant production relative to the total volume of mechanized works ranges from $35-50 \%$, which significantly affects the total production costs. Determining the optimal organization of transport, the formation of transport aggregate and transport means can affect the increase in the economy of production. The paper presents the results of research of transport aggregate and transport means for harvesting corn grains at the distance of: $1 \mathrm{~km}, 10 \mathrm{~km}, 15 \mathrm{~km}$. Based on the data processed, the most efficient transport aggregate is determined.

The results of the research of transport aggregates (A, B, C) show that they have made significant differences in the quantity of transported corn grain at different operating speeds.

At a distance of $1 \mathrm{~km}$, the transport aggregate (A) transported 150.4 tonnes of corn grains, with an average operating speed of $11.2 \mathrm{~km} \cdot \mathrm{h}^{-1}$, the transport aggregate (B) transported 104.58 tonnes of corn grains with an average operating speed from $7.41 \mathrm{~km} \cdot \mathrm{h}^{-1}$ and transport aggregate (C) transported 103.65 tonnes of corn grains with an average speed of $14.69 \mathrm{~km} \cdot \mathrm{h}^{-1}$.

At a distance of $10 \mathrm{~km}$, the transport aggregate (A) transported 27.64 tonnes of corn grains, with an average operating speed of $12.78 \mathrm{~km} \cdot \mathrm{h}^{-1}$, the transport aggregate (B) transported 72.50 tonnes with the average operating speed of $10.75 \mathrm{~km} . \mathrm{h}^{-1}$ and the transport aggregate (C) transported 187.50 tonnes of corn grains with an average operating speed of $23.25 \mathrm{~km} \cdot \mathrm{h}^{-1}$.

At a distance of $15 \mathrm{~km}$, the transport aggregate (A) transported 19.45 tonnes with an average operating speed of $17.00 \mathrm{~km} \cdot \mathrm{h}^{-1}$, the transport aggregate (B) transported 56.68 tonnes with an average operating speed of $15 \mathrm{~km} \cdot \mathrm{h}^{-1}$ and the transport aggregate (C) transported 143.5 tonnes of corn grain with an average operating speed of $30.50 \mathrm{~km} \cdot \mathrm{h}^{-1}$.
\end{abstract}

Keywords: aggregate, corn, transport, effectiveness, efficiency.

\footnotetext{
${ }^{1}$ Borislav Railić (corresponding author: borislav.railic@agrofabl.org), Zoran Maličević, Ljiljana Drinić, Agriculture University of Banja Luka, Faculty of Agriculture, BOSNIA AND HERZEGOVINA; Stevan Trivković, Inspection of Republika Srpska, BOSNIA AND HERZEGOVINA; Dragoljub Mitrović, Biotechical Faculty, Podgorica, MONTENEGRO.

Notes: The authors declare that they have no conflicts of interest. Authorship Form signed online.
} 


\section{INTRODUCTION}

Transport in agriculture is an integral part of the production process from which organization the economy of production depends. Modern, intensive agricultural production as well as transport of raw materials and finished products have caused application of modern transport aggregates and transport means. The organization of transport and the formation of a transport aggregate depends on : types of products, available transport means, road network, weather conditions, productivity of harvesting and harvesting machines and warehouses. (Novaković and Đević 1999).

The share of transport in plant production in relation to the total volume of mechanized works ranges from 35\% -50\% (Stanimirović et al 2008). For these reasons, transport in agriculture, with the complete organization and synchronization of transport means, significantly affects the productivity and cost-effectiveness of production. Planning and organization of transport is difficult due to the characteristics of agricultural production and the type of products and raw materials. According to research (Čuljt 1988) in agricultural production about $80 \%$ of product transport takes place (five months) from June to November.

The design of transport means for harvesting and proper selection depends on: the number of available combines, harvesting capacity, capacity of the bunker, and the distance of the production area to the warehouse. (Tatomirović and Velimirović 1977)

\section{MATERIAL AND METHOD}

Research on transport aggregates was carried out in 2014 in the area Dervente Republika Srpska.

The research methodology is based on the analysis of the influence of the transport aggregate structure and the transport medium depending on: the distance of the production parcel, the structure of the transport aggregate and the transport means, the transport efficiency, the volume and capacity of the vehicle, the aggregate movement speed, the loading time, the transport time, the unloading time, the duration of the transport cycle, the coefficient of time shift utilization $(\tau \mathrm{sm})$ and the efficiency of the transport aggregate and the transport means depending on the distance of the production parcel to the warehouse.

The harvesting of hybrid corn in the grains, ripening group 600, with a humidity

of $30-34 \%$, is intended for storage of silage in grain. Grain corn harvest

Based on work programs and established methods of work, organization of the harvest was based on the number of combines and their productivity. Based on the mentioned characteristics, the number and capacity of transport means was determined.

Corn grain transport was carried out by three transport aggregates, which were complemented in terms of manipulation of harvesters on the plot and during discharge. Based on the results of the research, the parameters as well as the mathematical data processing were summarized. In Table 1. the average results 
of the corn grain transport from different distances, the total cycle time, the number of cycles, and the timing shift coefficient $\left(\tau_{s m}\right)$ for each transport unit are given.

The productivity of the transport aggregate depends on the proper aggregation of the tractor with the trailer and the organization of transport.The traction force of the tractor is greater than the overall resistance of the transport aggregate. (Mitrović et al 2014)

$$
\mathbf{F}_{\mathbf{t}}>\mathbf{R}_{\mathbf{o r}}
$$

$\mathrm{F}_{\mathrm{t}}$ - traction force of tractor,

$\mathrm{R}_{\text {or }}$ - overall resistance of the transport aggregate.

The total resistance of the transport aggregate on a flat terrain depends: the total weight of the aggregates, the characteristics of the tractor, the characteristics of the empty trailer, the load and the conditions of the road surface.

$\mathrm{G}_{\mathrm{t}}$ - tractor mass,

$$
R_{\text {or }}=G_{p} \cdot f_{t} \cdot G_{f t} \cdot f_{t r}
$$

$\mathrm{G}_{\mathrm{ft}}$ - mass of full trailer and cargo,

$\mathrm{f}_{\mathrm{tr}}$ - trailer resistance coefficient,

$f_{t}$ - coefficient of resistance of tractor movement.

The number of trailers that the tractor can pull can be determined based on the equation:

$\mathrm{F}_{\mathrm{p}}$ - traction force of tractor

$$
\mathbf{n}=\mathbf{F}_{\mathbf{p}} / \mathbf{R}_{\mathbf{o r}}
$$

$\mathrm{R}_{\text {or }}$ - overall resistance of the transport aggregate

When assembling the tractor aggregate (tractor + trailer), the ratio of the total weight of the trailer and the weight of the tractor is important:

$f_{a}$ - aggregation coefficient

$$
\boldsymbol{f}_{\mathbf{a}}=\mathbf{G}_{\mathbf{f t}} / \mathbf{G}_{\mathbf{t}}
$$

$\mathrm{G}_{\mathrm{p}}$ - mass of full trailer and cargo

$\mathrm{G}_{\mathrm{t}}$ - tractor mass

The productivity of the transport aggregate can be determined on the basis of the equation:

$$
\mathbf{W}_{\mathbf{t a}}=\mathbf{G}_{\mathbf{c a r}} \cdot \mathbf{n}_{\mathbf{c y}}
$$

$\mathrm{W}_{\mathrm{ta}}{ }^{-}$productivity of the transport aggregate

$\mathrm{G}_{\text {car }}$ - cargo mass

$\mathrm{n}_{\mathrm{cy}}-$ number of cycles of transport aggregate.

$$
\mathbf{n}_{\mathbf{c y}}=\mathbf{T}_{\mathbf{g t}} \cdot \mathbf{C}_{\mathbf{u t}} / \mathbf{t}_{\mathbf{c y}}
$$

$\mathrm{T}_{\mathrm{gt}}-$ total working time per day (gross time)

$\mathrm{C}_{\mathrm{ut}}$ - coefficient of time use

$\mathrm{t}_{\mathrm{cy}}$ - the duration of one cycle 
The duration of one cycle of transport aggregate $\left(\mathrm{t}_{\mathrm{cy}}\right)$ depends on: trailer load, trailer number, trailer loading time, transport time, type of substrate, unloading time and work organization, (Mitrović et al. 2014).

The duration of one cycle of the transport aggregate can be determined on the basis of the equation:

$$
t_{c y}=t_{l o}+t_{d i s}+t_{t f t}+t_{\text {tet }}+t_{c h}
$$

$\mathrm{t}_{\mathrm{lo}}$ - loading time,

$\mathrm{t}_{\text {dis }}$ - discharge time (unloading),

$t_{\text {tet }}$ - the time of empty trailer transport

$t_{t f t}$ - the time of transport full trailers

$\mathrm{t}_{\mathrm{ch}}$ - checking time.

The required number of transport aggregates, in the transport of certain products and materials,depends primarily on the volume of transport and productivity (performance) of the machine transport unit, and it is determined on the basis of the equation:

$$
\mathbf{n}_{\mathbf{t a}}=\mathbf{Q}_{\mathbf{u k}} / \mathbf{W}_{\mathbf{t}}
$$

$\mathrm{n}_{\mathrm{ta}}-$ number of transport aggregate

$\mathrm{W}_{\mathrm{t}}$ - productivity of the transport aggregate

$\mathrm{Q}_{\mathrm{vt}}-$ total volume of transport

$\mathrm{G}_{\mathrm{t}}$ - mass of tractor

$$
\mathbf{n}_{\mathbf{t a}}=\mathbf{Q}_{\mathbf{u k}} / \mathbf{G}_{\mathbf{t}} \cdot \mathbf{n}_{\mathbf{c y}}
$$

$\mathrm{n}_{\mathrm{cy}}-$ the duration of one cycle.

Coefficient of time shift utilization $\left(\tau_{s m}\right)$ for achieving technological useful work is determined based on the equation:

$\tau_{\mathrm{sm}}$ - coefficient of time shift utilization

$$
\tau_{s m}=t_{u k} / T_{s}
$$

$\mathrm{t}_{\mathrm{cy}}-$ total transport cycle duration

$\mathrm{T}_{\mathrm{s}}$ - time of shift

Depending on the conditions and complexity of the technological process, the coefficient of time shift utilization is different. Under the test conditions, the minimum coefficient is 0.34 for the transport aggregate (C) at a distance of $1 \mathrm{~km}$, while for the transport aggregate $(C)$ the maximum is 1.0 at a distance of $10 \mathrm{~km}$. At a distance of $1 \mathrm{~km}$, the resulting coefficient for the transport aggregate (A) was 0.72 , for transport aggregate (B) was 0.44 and for transport aggregate (C) was 0.34 .

At a distance of $10 \mathrm{~km}$, the resulting coefficient for the transport aggregate (A) was 0.62 , for transport aggregate (B) was 0.96 and for transport aggregate was (C) 1.0 . 
At a distance of $15 \mathrm{~km}$, the resulting coefficient for the transport aggregate (A) was 0.54, for transport aggregate (B) was 0.87 and for transport aggregate (C) was 0.98 .

The coefficient of time shift utilization was significantly influenced by the distance of the production plot from the economic yard, which can be concluded that the transport aggregate (A) at the distance of the production area of $1 \mathrm{~km}$ achieved the highest coefficient.

Considering the conditions and complexity of the technological process, as well as congestion due to technical, organizational and personal character, the value of the coefficient of time shift utilization in the transport aggregate (A) was 0.72 , which was characterized by the mobility and the possibility of accessing combines on the plot.

The transport cycle consists of empty driving, loading, freight and unloading. The duration of each operation is required by the time dimension (Marković, D., 1997) and can be determined on the basis of the equation:

$$
t_{u k}=t_{o}+t_{u}+t_{p}+t_{i}
$$

\section{RESULTS AND DISCUSSION}

Observing the number of cycles performed for each transport aggregate, from different distances, the result was that the transport aggregate (A) at a distance of $1 \mathrm{~km}$, performed 20 cycles, the transport aggregate (B) 7 cycles and the transport aggregate (C) 5 cycles.

At a distance of $10 \mathrm{~km}$ the transport aggregate (A) has performed 4 cycles, transport aggregate (B) 5 cycles and transport aggregate (C) 9 cycles.

At a distance of $15 \mathrm{~km}$, the transport aggregate (A) has performed 3 cycles, transport aggregate (B) 4 cycles and transport aggregate (C) 7 cycles. On smaller distances, the more mobile transport aggregate $(\mathrm{A})$ performed several cycles more in contrast to the vehicle $(\mathrm{C})$, and in the case of a larger distance, the situation is inverted.

The carrying capacity of the transport unit, the number and structure of transport means has been affected by the duration of the transport cycle. The loading time $\left(t_{u}\right)$ can be achieved by applying a self - loading trailer with a bunker that can monitor the work of the harvester and harvested grain unloading in the means of transport at the end of the parcel

Driving with load $\left(t_{l}\right)$, depends on transport speed with load, distance and road network status.

Time of unloading $\left(t_{u l}\right)$ appears as inevitability in the duration of the transport cycle, and depends on the method of discharging the transport means.

Table 2. shows the quantities of transported corn grains, from which it can be concluded that transport aggregates $\mathrm{A}, \mathrm{B}, \mathrm{C}$ transported different quantities depending on the distance of the parcels.

The transport aggregate (A), at a distance of $\mathbf{1} \mathbf{~ k m}$, transported 150.4 tonnes or $42.0 \%$ of the total 358.6 tonnes of transported corn grains. The 
transport aggregate (B) transported 104.58 tonnes or $29.2 \%$ of the total, and the transit aggregate $(\mathrm{C})$ transported $103.65 \mathrm{t}$ or $28.9 \%$.

Table 1. Average results: duration of the cycle, number of cycles and coefficient of time shift utilization $\left(\tau_{s m}\right)$

\begin{tabular}{|c|c|c|c|c|c|c|c|}
\hline \multirow{2}{*}{$\begin{array}{l}\text { Transport } \\
\text { aggregate }\end{array}$} & \multicolumn{5}{|c|}{ Duration of the transport cycle $(\mathrm{min})$} & \multirow[b]{2}{*}{$\tau_{s m}$} & \multirow{2}{*}{$\begin{array}{c}\text { Number of } \\
\text { transport } \\
\text { cycles }\end{array}$} \\
\hline & $t_{o}$ & $t_{u}$ & $t_{p}$ & $t_{i}$ & $t_{u k}$ & & \\
\hline \multicolumn{6}{|c|}{ distance $1 \mathrm{~km}$} & & \\
\hline A & 4,40 & 8,36 & 5,40 & 3,41 & 21,57 & 0,72 & 20 \\
\hline $\mathrm{B}$ & 5,10 & 18,12 & 8,10 & 6,10 & 37,42 & 0,44 & 7 \\
\hline $\mathrm{C}$ & 3,45 & 28,14 & 4,08 & 4,48 & 40,16 & 0,34 & 5 \\
\hline \multicolumn{6}{|c|}{ distance $10 \mathrm{~km}$} & & \\
\hline A & 33,44 & 8,36 & 47,00 & 3,07 & 91,87 & 0,62 & 4 \\
\hline $\mathrm{B}$ & 35,00 & 18,12 & 56,00 & 6,06 & 115,18 & 0,96 & 5 \\
\hline $\mathrm{C}$ & 15,34 & 28,10 & 26,00 & 4,10 & 73,54 & 1,11 & 9 \\
\hline \multicolumn{6}{|c|}{ distance $15 \mathrm{~km}$} & & \\
\hline A & 44,00 & 8,38 & 52,00 & 3,03 & 107,41 & 0,54 & 3 \\
\hline B & 47,33 & 18,13 & 60,00 & 6,07 & 131,53 & 0,87 & 4 \\
\hline $\mathrm{C}$ & 22,00 & 28,13 & 30,00 & 4,10 & 84,23 & 0,98 & 7 \\
\hline
\end{tabular}

Table 2. Amount of transported corn per transport means

\begin{tabular}{|c|c|c|c|c|c|c|}
\hline \multirow{2}{*}{$\begin{array}{l}\text { Transport } \\
\text { aggregate }\end{array}$} & \multirow{2}{*}{$\begin{array}{l}\text { Number of } \\
\text { transport } \\
\text { cycles }\end{array}$} & \multicolumn{4}{|c|}{ Amount of transported corn } & \multirow{2}{*}{$\begin{array}{l}\text { Percentage } \\
\text { of } \\
\text { participation } \\
\text { in transport } \\
\text { (Pup) }\end{array}$} \\
\hline & & $\begin{array}{c}\text { By cycle } \\
(t)\end{array}$ & $t$ & $t k m$ & $t \mathrm{~km} / \mathrm{h}$ & \\
\hline \multicolumn{6}{|c|}{ distance $1 \mathrm{~km}$} & \\
\hline A & 20 & 7,52 & 150,40 & 150,40 & 15,04 & 42,00 \\
\hline B & 7 & 14,94 & 104,58 & 104,58 & 10,46 & 29,20 \\
\hline $\mathrm{C}$ & 5 & 20,73 & 103,65 & 103,65 & 10,37 & 28,90 \\
\hline \multicolumn{3}{|c|}{ in total } & 358,63 & & & \\
\hline \multicolumn{6}{|c|}{ distance $10 \mathrm{~km}$} & \\
\hline A & 4 & 6,91 & 27,64 & 276,40 & 27,64 & 9,62 \\
\hline B & 5 & 14,50 & 72,50 & 725,00 & 72,50 & 25,20 \\
\hline $\mathrm{C}$ & 9 & 20,83 & 187,50 & 1875,00 & 187,50 & 65,25 \\
\hline \multicolumn{3}{|c|}{ in total } & 287,34 & & & \\
\hline \multicolumn{6}{|c|}{ distance $15 \mathrm{~km}$} & \\
\hline $\mathrm{A}$ & 3 & 6,48 & 19,45 & 291,75 & 29,18 & 8,86 \\
\hline $\mathrm{B}$ & 4 & 14,17 & 56,68 & 850,20 & 85,02 & 25,81 \\
\hline $\mathrm{C}$ & 7 & 20,50 & 143,50 & 2152,50 & 215,25 & 65,34 \\
\hline \multicolumn{3}{|c|}{ in total } & 219,63 & & & \\
\hline
\end{tabular}


At a distance of $10 \mathrm{~km}$, the transport aggregate (A) transported 27.64 tonnes or $9.62 \%$ of the total 287.34 tonnes of transported corn grains, transport aggregate (B) transported 72.5 tonnes or $25.2 \%$ of the total transported corn grains and the transport aggregate (C ) transported 187.5 tonnes or $65.25 \%$ of total transported corn grains.

At a distance of $15 \mathrm{~km}$, the transport aggregate (A) transported 19.45 tonnes or $8.86 \%$ of the total 219.63 tonnes of transported corn grains, the transport aggregate (B) transported 56.68 tonnes or $25.81 \%$ of total, and the transport aggregate (C) transported 143.50 tonnes or $65.34 \%$ of total transported corn grains.

The research results show that the transport aggregate (A) is more mobile than other two aggregates and at a smaller distance, transport aggregate (A) transported a larger amount of corn grains than the transport aggregate (C).

Comparing the results (Table 2) the transport aggregates efficiency is directly proportional to the increase of aggregates capacity and distance plots of the economic yard. If the productivity is expressed in $(\mathrm{tkm} / \mathrm{h})$, it is reversely proportional if the productivity is expressed in $(\mathrm{t} / \mathrm{h})$.

\section{CONCLUSION}

Presented data show that the problem of transport in agriculture is very complex and that in the current conditions of agricultural production with higher yields it becomes a brake on its further development, if it is not equipped with modern means of transportation.

At greater distances, transport with the truck in relation to the transport with tractor (tractor + trailer) has a greater advantage. At a distance of $15 \mathrm{~km}$, the truck transported $65.34 \%$ while the tractor (tractor + trailer) transported $8.86 \%$ of the total quantity, which is 7.36 times more.

At smaller distances, productivity $(\mathrm{t} / \mathrm{h})$ is important because it is growing, while at larger distances it is decreasing.

The structure of the transport aggregate has shown that the transport aggregate (A) at a distance of $1 \mathrm{~km}$ has priority over other transport aggregates for easier manipulation on the plot.

Transport means such as a container or a specialized trailer represent a better conceptual, technical and technological solution that affects transport efficiency and cost-effectiveness.

Solving the rationalization of transport, especially internal in agricultural production, is not enough to solve in the field, but it should be addressed in the warehouse and later in the production, packaging and transport to consumers.

Since transport in agriculture is specific, it is necessary to abide by the directive of the European Parliament and the Council of Europe on transport in agriculture. The influential transport factors are: the structure of the transport aggregate, the road network, the transport distances, the volume and load capacity of the transport meeans, the movement speed, the time of loading and unloading of the product or repro materials. 


\section{REFERENCES}

Čuljt, M. Suvremeno ubiranje žitarica i drugih ratarskih kultura. Agrotehničar, Zagreb,1988.

Marković, D. Transport u poljoprivredi Mašinski fakultet, Beograd, 1997.

Mitrović, D., Railić, B., Maličević, Z., Jugović, M.(2014).: Knjiga, Mehanizacija i oprema u stočarstvu, Poljoprivredni fakultet Banja luka.

Mitrović, D., Railić,B., Maličević, Z., Jugović, M.(2014).: Knjiga, Eksploatacija i održavanje poljoprivrednih mašina, Poljoprivredni fakultet Banja luka.

Novaković, D., Đević, M.(1999). : Knjiga, Transport u poljoprivredi. Poljoprivredni fakultet Beograd.

Stanimirović, N., Koprivica, R., Stevović, V., Veljković, B. (2008): Gubici pri transportu iseckane silomase kukuruza od parcele do silo objekta, Savremena poljoprivredna tehnika godina 34. broj $3-4$ strana $158-162$. Beograd.

Tatomirović, M., Velimirović, S. (1977).: Knjiga, Transport u proizvodnji poglavlje V Transport, skladištenje proizvoda i rukovanje proizvodima u oblasti poljoprivredne proizvodnje. Beograd. 